\title{
Antimicrobial activity of essential oils extracted from clove and lemongrass against pathogenic bacteria isolated from bovine, swine and poultry feces
}

\section{Atividade antimicrobiana de óleos essenciais extraídos de cravo-da- índia e capim-limão contra bactérias patogênicas isoladas de fezes de bovinos, suínos e aves}

\author{
Stephanie Pedrosa de Oliveira ${ }^{1}$; Gabriel Santos Persiquini Cunha ${ }^{2}$; João Paulo \\ Bicalho Prates ${ }^{2}$; Francine Souza Alves Fonseca ${ }^{3}$; Keicy Sandy Silvestre de Souza ${ }^{2}$; \\ Alcinei Místico Azevedo ${ }^{4}$; Alessandra Rejane Ericsson de Oliveira Xavier ${ }^{5}$; Eliane \\ Macedo Sobrinho Santos ${ }^{6}$; Hércules Otacílio Santos ${ }^{7}$; Anna Christina de Almeida ${ }^{4 *}$
}

\begin{abstract}
The objective was to verify the antibacterial activity of lemongrass and clove oils against Escherichia coli isolated from poultry feces, Staphylococcus aureus isolated from swine and poultry feces and Salmonella sp. isolated from swine and bovine feces. The antimicrobial activity was evaluated by the disc diffusion test using different concentrations of the oils: 160, 80, 40, 20 and $10 \mu 1 \mathrm{ml}^{-1}$. The multi-resistance of strains relative to that of conventional antimicrobials was also evaluated by the disk diffusion technique, using Multiple Antibiotic Resistance (MAR) index. The oils were characterized based on the results of chromatographic analyses, of which, analysis of lemongrass has been previously published (AZEVEDO et al., 2016). Lemongrass and clove essential oils presented citral and eugenol as the major compound, respectively. The concentrations of the essential oils had a significant effect on the extent of the growth inhibition halo and the coefficient of determination $\left(\mathrm{r}^{2}\right)$ was higher than 0.80 . Clove essential oil generated the largest zone of inhibition when tested against Escherichia coli and S. aureus from poultry feces and Salmonella sp. from the feces of swine, while lemongrass essential oil presented better results against $S$. aureus isolated from swine feces and Salmonella sp. from bovine feces. $S$. aureus and Salmonella sp. were multi-resistant to the antimicrobials tested. It is concluded that the essential oils tested have antimicrobial activity against bacteria isolated from bovine, swine, and poultry feces and that this activity is proportional to the concentration of oils and the microorganisms studied. Key words: Antimicrobial. Clove. Cymbopogon flexuosus. Lemongrass. Syzygium aromaticum.
\end{abstract}

1 Discente do Curso de Mestrado, Programa de Pós-Graduação em Produção Animal, Instituto de Ciências Agrárias, Universidade Federal de Minas Gerais, UFMG, Montes Claros, MG, Brasil. E-mail: stephanie_pedrosa_92@hotmail.com

2 Mestres em Produção Animal, Instituto de Ciências Agrárias, UFMG, Montes Claros, MG, Brasil. E-mail: gspzoo@outlook. com; jpaulobprates@yahoo.com.br; keicysandy@yahoo.com.br

3 Pós-Doutora em Produção Vegetal, Docente Visitante Instituto de Ciências Agrárias, UFMG, Montes Claros, MG, Brasil. E-mail: francinefonseca@yahoo.com.br

4 Profs., Instituto de Ciências Agrárias, UFMG, Montes Claros, MG, Brasil. E-mail: alcineimistico@hotmail.com; aca2006@ica. ufmg.br

5 Prof., Universidade Estadual de Montes Claros, UNIMONTES, Centro de Ciências Biológicas e da Saúde, Departamento de Fisiopatologia, Laboratório de Microbiologia, Montes Claros, MG, Brasil. E-mail: ericsson_aerc@yahoo.com.br

${ }^{6}$ Prof ${ }^{a}$, Instituto Federal do Norte de Minas Gerais, IFNMG, Araçuai, MG, Brasil. E-mail: eliane.santos@ifnmg.edu.br

7 Médico Veterinário, IFNMG, Araçuai, MG, Brasil. E-mail: htacilio@hotmail.com

Author for correspondence 


\section{Resumo}

Objetivou-se verificar a atividade antibacteriana dos óleos de capim-limão e cravo-da-índia frente à Escherichia coli isolada de fezes de aves, Staphylococcus aureus isolado de fezes de suínos e aves e Salmonella sp. isolado de fezes de suínos e bovinos. A atividade antimicrobiana foi avaliada pelo teste de difusão em disco utilizando diferentes concentrações dos óleos: 160, 80, 40, 20 e $10 \mu 1 \mathrm{ml}^{-1}$. A multirresistência de cepas em relação à antimicrobiana convencional também foi avaliada pela técnica de disco-difusão, utilizando-se o índice de resistência múltipla a antibióticos (MAR). Os óleos foram caracterizados com base nos resultados de análises cromatográficas, das quais, a análise de capimlimão já foi publicada anteriormente (AZEVEDO et al., 2016). Os óleos essenciais de erva-cidreira e cravo apresentaram citral e eugenol como o principal composto, respectivamente. As concentrações dos óleos essenciais tiveram um efeito significativo no comprimento do halo de inibição do crescimento e o coeficiente de determinação $\left(\mathrm{r}^{2}\right)$ foi superior a 0,80 . O óleo essencial de cravo-da-índia gerou a maior zona de inibição quando testado frente á Escherichia coli e S. aureus a partir de fezes de aves e Salmonella sp. das fezes de suínos, enquanto o óleo essencial de capim-limão apresentou melhores resultados frente á S. aureus isolado de fezes de suínos e Salmonella sp. de fezes de bovinos. S. aureus e Salmonella sp. foram multirresistentes aos antimicrobianos testados. Conclui-se que os óleos essenciais testados possuem atividade antimicrobiana contra bactérias isoladas de fezes de bovinos, suínos e aves e que essa atividade é proporcional à concentração de óleos e microrganismos estudados.

Palavras-chave: Antimicrobiano. Cravo-da-índia. Cymbopogon flexuosus. Capim-limão. Syzygium aromaticum.

\section{Introduction}

The use of antibiotics in animal production as performance enhancers or growth promoters enable improved dietary absorption, reduced mortality, increased growth and productivity, and improved health and disease resistance (GONZALES et al., 2012). However, their indiscriminate use has led to high rates of multi-resistance in microorganisms, and, at present one of the biggest challenges in the area of animal production is the search for alternatives to reduce the use of antimicrobials in animal feed (COSTA et al., 2007).

The control of bacterial pathogens in animal production systems is an important step in food safety. Alternative products, such as essential oils, may have application in the treatment of production animals to reduce the pathogenic load.

Essential oils are studied for the possibility of obtaining alternative animal and human feed components as well as medicinal products, as much for their activity on clinical isolates as well as for their safety with respect to the animal, environment, and man. Studies indicate that the benefit of using essential oils in diet on performance is due to the increase in the palatability of the diet, stimulation of endogenous enzyme secretion and digestive function, and control of the intestinal microflora, besides helping in reducing subclinical infections (PICKLER et al., 2011). Among the essential oils studied are the extracts of lemongrass and clove.

Cymbopogon flexuosus, known as lemongrass, has as its major component, citral, which is formed by two general geraniale isomers. The essential oil of lemongrass presents antifungal, antimicrobial, antitumoral, and other activities (DESAI; PARIKH, 2012).

Syzygium aromaticum, known as clove, has eugenol as its major component and to a lesser extent also has the acetate of eugenila and $\beta$-caryophyllene. It has several therapeutic functions such as antidiabetic, antitumor, antioxidant, antimicrobial, and antifungal activities among others (AFFONSO et al., 2012).

Studies on the use of essential oils in animal production have increased and these demonstrate the high potential of essential oils in controlling a large number of pathogens including multi- 
resistant bacteria and foodborne pathogens (BURT, 2004; HYLDGAARD et al., 2012; FALEIRO; MIGUEL, 2013).

Although the literature points to studies demonstrating the bactericidal or bacteriostatic action of the oils mentioned above, no study has so far addressed the ability of these oils to inhibit pathogenic bacteria isolated from bovine, swine and poultry feces, with the aim of suggesting alternatives to conventional microbes routinely used in disease prevention in animal production.

This study aimed to verify the antibiotic resistance of Salmonella sp. isolated from bovine and swine feces, Escherichia coli isolated from poultry feces, and Staphylococcus aureus isolated from swine and poultry feces, against the antibacterial activity of the essential oils extracted from lemongrass (Cymbopogon flexuosus Steud. Wats) and clove (Syzygium aromaticum (L.) Merr. \& Perry).

\section{Material and Method}

\section{Target microorganisms}

Strains of Salmonella sp. was isolated from bovine (08) and swine (08) feces, strains of Escherichia coli was isolated from poultry (08) feces, and strains of Staphylococcus aureus was isolated from swine (08) and poultry (08) feces stored in the bacteriotheca of the Laboratory of Animal Health of the Universidade Federal de Minas Gerais (UFMG) at the Campus of Montes Claros - MG. These strains were identified by microbiological analyses conducted previously (QUINN et al., 2005) and were stored in glycerol at $-18^{\circ} \mathrm{C}$. Aliquots of these strains were activated in Brain Heart Infusion (BHI) broth by two subcultures and subjected to purity assessment before use in the tests (ANVISA, 2006).

\section{Antimicrobial susceptibility test}

Microbial strains were submitted to antimicrobial sensitivity tests performed by the disc diffusion method (CLINICAL AND LABORATORY STANDER INSTITUTE, 2015). Sulfazotrim (25 $\mu \mathrm{g})$, Norfloxacin $(10 \mu \mathrm{g})$, Ciprofloxacin $(5 \mu \mathrm{g})$, Gentamicin $(10 \mu \mathrm{g})$, Tetracycline $(30 \mu \mathrm{g})$, and Oxacillin $(1 \mu \mathrm{g})$ were obtained commercially. The antimicrobial multi-resistance of the strains tested was evaluated using the Multiple Antibiotic Resistance (MAR) index, adopting the recommendation of Krumperman et al. (1983). The bacterial strain was considered multidrug resistant when one isolate presented simultaneous resistance to two or more antimicrobial drugs.

\section{Source of essential oils}

Lemongrass essential oil (Cymbopogon flexuosus Steud. Wats, Poaceae) was commercially acquired from Ferquima Industry and Commerce LTDA (Vargem Grande Paulista, São Paulo, Brazil). Extraction was carried out by steam distillation of freshly harvested leaves and chemically characterized by gas chromatography in a previous study (AZEVEDO et al., 2016).

In order to obtain clove essential oil (Syzygium aromaticum (L.) Merr. \& Perry, Myrtaceae), the dried flower buds were purchased commercially and the oil was extracted in the Laboratory of Medicinal Plants of ICA-UFMG using the technique of hydrodistillation by steam drag (CRAVEIRO et al., 1981) with Clevenger extractor.

Chromatographic analyses were performed by the Laboratory of Instrumental Chemistry - Institute of Agrarian Sciences of UFMG, using a gas chromatograph (Agilent Technologies; GC 7890a) adopting a method similar to that performed in a study by Azevedo et al. (2016).

\section{Essential oils sensitivity test}

The antibacterial activity of lemongrass and clove oils against the bacterial strains under investigation was also evaluated by the adapted disc diffusion 
technique (CLINICAL AND LABORATORY STANDER INSTITUTE, 2015). In order to obtain the desired concentrations for the two oils, $400 \mu$ l of the essential oils tested, $20 \mu 1$ Tween 80 emulsifier, and $2.08 \mathrm{ml} \mathrm{BHI}$ were used, resulting in a $2.5 \mathrm{ml}$ solution of concentration $160 \mu \mathrm{m} \mathrm{l}^{-1}$ subsequent concentrations of $80 \mu \mathrm{l} \mathrm{ml}{ }^{-1}, 40 \mu 1 \mathrm{ml}^{-1}, 20 \mu \mathrm{l}$ $\mathrm{ml}^{-1}$ and $10 \mu \mathrm{ml}^{-1}$ were obtained through serial dilutions from the $160 \mu 1 \mathrm{ml}^{-1}$.

After the desired concentrations of the oils were obtained, $30 \mu \mathrm{l}$ of each was deposited on sterile filter paper discs, with a diameter of $6 \mathrm{~mm}$. After complete saturation, the discs were allowed to stand to dry the oil. The inoculums of the microbial strains under study were obtained according to the standard scale of Mac Farland 0.5. Commercial antibiotic disks Ciprofloxacin $(5 \mu 1)$, Tween 80 and discs impregnated with distilled water were used as control in the tests. Mueller Hinton Agar was used as medium and the plates were incubated at $37^{\circ} \mathrm{C}$ for $24 \mathrm{~h}$. The measurements of the halo or inhibition zone were made with a millimeter ruler.

\section{Statistical analyzes}

Inhibitory effects of the essential oils against the test bacteria were expressed as mean \pm standard error of mean of the inhibition zone diameter ( $\mathrm{mm}$ ) using the two-way ANOVA test in the statistical program GraphPad prism with significance level of $5 \%$. The linear regression analysis was carried out to determine the correlations between different concentrations of the essential oils and their antibacterial activity at the maximum inhibition zone diameters. The standard dose-response curves were obtained by tracing the concentrations of essential oil $\left(\mu \mathrm{l} \mathrm{ml}{ }^{-1}\right)$ against the mean diameter of the inhibition zone ( $\mathrm{mm}$ ) for this purpose and adjusted for first-degree polynomial regression models. To test the significance of the regression coefficients, the t-test was used. To compare if the regression models obtained for lemongrass and clove were statistically the same or different (Ho: $\beta 1=\beta 2$ vs. Ha: $\beta 1 \neq \beta 2, \beta$ being the parameter vector of the linear model), we resorted to model identity test. These statistical analyzes were done in the GENES software. For the evaluation of the sensitivity patterns of the microorganisms to conventional antimicrobials, the chi-square test was used.

\section{Results and Discussion}

In the evaluation of multiple antibiotic resistance for isolated strains from swine feces, it was found that for Salmonella sp. the MAR value was 0.83 and for S. aureus the value of 0.67 was observed. For the isolates from poultry feces, the MAR for S. aureus was 0.83 and for $E$. coli the value was 0.16 . For the isolates of Salmonella sp. in bovine feces the MAR value was 0.16. According to Krumperman et al. (1983), values equal to 0.2 or higher are indicative of bacterial multi-resistance. Thus, multi-resistance was observed in swine and poultry isolates, indicating resistance of the bacteria to antimicrobials frequently used (VARGHESE; ROYMON, 2013).

In case of Salmonella sp., it was observed that the origin of the strains influenced the resistance to most antibiotics $(\mathrm{p}<0.01)$ (Table 1). For $S$. aureus in relation to resistance to the antimicrobials tested, the origin did not influence the resistance frequency ( $p>0.05)$ (Table 1), as well as the multi-resistance of the isolates of swine and poultry with MAR above 0.2 . When analyzing the resistance frequency of the studied $S$. aureus strain, the strain showed resistance to $83.33 \%$ of the antimicrobials tested. Since E. coli was only isolated from poultry, this analysis was not relevant. 
Table 1. Frequency of the resistance of microorganisms isolated from bovine, swine and poultry feces to conventional antibiotics, using the disk diffusion technique.

\begin{tabular}{|c|c|c|c|c|c|c|}
\hline & \multicolumn{2}{|c|}{ Salmonella sp. } & \multicolumn{2}{|c|}{ S. aureus } & \multirow{2}{*}{$\begin{array}{l}\text { S. aureus X Salmonella } \\
\text { sp. X E.coli }\end{array}$} & \multirow{2}{*}{$\begin{array}{l}\text { Poultry X Bovine } \\
\text { X Swine }\end{array}$} \\
\hline & \multicolumn{2}{|c|}{ Bovine and Swine } & \multicolumn{2}{|c|}{ Poultry and Swine } & & \\
\hline Antibiotics & $P$ value & $\begin{array}{l}\text { Resistant } \\
\text { Frequency (\%) }\end{array}$ & $P$ value & $\begin{array}{l}\text { Resistant } \\
\text { Frequency (\%) }\end{array}$ & $P$ value & $P$ value \\
\hline SUL & 0.0001 & $62.5 \%$ & 0.3017 & $93.75 \%$ & 0.0074 & 0.0020 \\
\hline NOR & 0.0000 & $50 \%$ & 1.0000 & $100 \%$ & 0.0000 & 0.0000 \\
\hline CIP & 0.0000 & $50 \%$ & 0.3017 & $87.5 \%$ & 0.0001 & 0.0001 \\
\hline GEN & 0.1025 & $0 \%$ & 0.3017 & $6.25 \%$ & 0.4634 & 0.4634 \\
\hline TET & 0.0003 & $62.5 \%$ & 0.0547 & $81.25 \%$ & 0.0001 & 0.0013 \\
\hline OXA & 0.0088 & $81.25 \%$ & 1.0000 & $100 \%$ & 0.1353 & 0.0132 \\
\hline
\end{tabular}

Sulfazotrim (SUL); Norfloxacin (NOR); Ciprofloxacin (CIP); Gentamicin (GEN); Tetracyclines (TET); Oxacillin (OXA).

When comparing the resistance of the strains of $S$. aureus, Salmonella, and E. coli to the different types of antibiotics, it is verified that there is no relationship between resistance of the strains with respect to their origin against the antibiotics Oxacillin $(p=0)$ and Norfloxacin $(p=0)$, where $100 \%$ of the strains were resistant, as well as to gentamicin $(p=0.4634)$, which was associated with a lower resistance frequency $(6.25 \%)$. Similar behavior can be noticed when comparing the animal species in relation to the resistance to these same antimicrobials. Resistance to the antibiotics Sulfazotrim, Ciprofloxacin, and Tetracycline was observed to be influenced by the strains as well as the origin of the strains (Table 1).

Antimicrobials in animal production are used for promoting animal growth, prophylaxis, and therapeutic treatment and prevention (HUDSON et al., 2017). However, excessive and indiscriminate use may result in strains not being susceptible to even one agent in three or more classes of antibiotics (MAGIORAKOS et al., 2012).

Although high resistance to oxacillin has been observed, this antibiotic is not used in commercial feed additives. Thus, resistance to this antibiotic can be explained by resistance to the beta-lactam group (SILVA; LINCOPAN, 2012), and may be caused by a naturally occurring response owing to pressure of exposure to the inappropriate use of this antimicrobial (HOLMES et al., 2016).

The chromatographic analysis of lemongrass essential oil showed it possible to detect that the major component was citral with $77.42 \%$ (AZEVEDO et al., 2016), which may be the compound associated with the antimicrobial activity of the oil. Citral (3,7-dimethyl-2,6-octadienyl) is a natural mixture of two acyclic mono-terpene aldehydes isomers: geranial (trans-citral, citral A) and mineral (ciscitral, citral B), which can be isolated from the leaves and fruits of a wide variety of citrus plants and also shows significant activity against various pathogens (FISHER; PHILLIPS, 2006). Citral acts by disrupting the cytoplasmic and outer membrane of Escherichia coli cells and the RpoS sigma factor, which is involved in the E. coli response to citral damage (SOMOLINOS et al., 2009).

The analysis of the components of clove essential oil (Table 2) indicated eugenol (79.4\%) as the major compound, which may be responsible for antimicrobial activity (XIE et al., 2015). Eugenol, a phenylpropanoid, is the main component of the oil (Syzygium aromaticum) acting against both gram-positive and gram-negative bacteria, affecting membrane permeability and glucose uptake and utilization (DI PASQUA et al., 2006; DEVI et al., 2010). 
Table 2. Relative abundance (\%) of the compounds identified by CG-MS of essential oil extracted from Syzygium aromaticum.

\begin{tabular}{llllll}
\hline $\mathbf{N}^{\circ}$ & $\mathrm{RT}_{(\min )}$ & Compounds & $\mathbf{I R}_{\text {cal }}$ & $\mathbf{I R}_{\text {Lit }}$ & Relative abundance (\%) \\
\hline 28 & 21.70 & Eugenol & 1353 & 1356 & 79.40 \\
33 & 24.30 & (E)-Cariofileno & 1415 & 1417 & 7.29 \\
36 & 25.80 & Humuleno & 1451 & 1453 & 1.14 \\
42 & 28.20 & Desconhecido & 1512 & - & 11.16 \\
43 & 28.30 & ס-Cadineno & 1514 & 1513 & 0.33 \\
47 & 30.70 & Óxido de cariofileno & 1575 & 1582 & 0.65 \\
\hline
\end{tabular}

$\mathrm{RT}_{(\min )}$ : retention time. $\mathrm{RI}_{c a l}:$ Calculated Retention Index. $\mathrm{RI}_{\text {Lit }}$ : Retention Index of the literature. (-) Compounds not detected.

The chromatographic analysis of the two oils showed that they had the chemical compounds responsible for antimicrobial activity against bacteria isolated from other sources, not only against bacteria isolated from feces of production animals. The European Commission has accepted both eugenol and citral as conservation agents in food products, because of the effectiveness of their antimicrobial activity, via Regulation 872/2012 (COMISSÃO EUROPEIA, 2012).
In the present study, when analyzing the diameter of bacterial growth inhibition halos of clove oil using first degree polynomial regression (Table 3), it was observed that the tested concentrations of the essential oils analyzed had a significant result in relation to the halo diameter, with all coefficients of determination $\left(\mathrm{r}^{2}\right)$ greater than 0.80 , indicating good quality of the regression fit and all estimates of the p-value of the model identity test point to be significant at the $1 \%$ level. This shows that in all cases, the regression curves obtained for lemongrass and clove differed significantly.

Table 3. Adjusted linear regression equations to model the extent of the growth inhibition halo of fecal bacteria from different animals as a function of concentrations of lemongrass and clove oils.

\begin{tabular}{|c|c|c|c|c|}
\hline Animals & Bacterium & Oil & Equation & TIM (p-Value) \\
\hline \multirow{2}{*}{ Poultry } & S. aureus & $\begin{array}{l}\text { Lemongrass } \\
\text { Clove }\end{array}$ & $\begin{array}{l}\mathrm{y}=-1.094 *+0.060 * * \mathrm{xr}^{2}=0.936 \\
\mathrm{y}=-2.271 *+0.077 * * \mathrm{xr}^{2}=0.865\end{array}$ & $<0.001$ \\
\hline & E.coli & $\begin{array}{l}\text { Lemongrass } \\
\text { Clove }\end{array}$ & $\begin{array}{l}y=-0.609^{\mathrm{n}}+0.023 * \mathrm{xr}^{2}=0.931 \\
\mathrm{y}=-1.667^{*}+0.072 * * \mathrm{xr}^{2}=0.966\end{array}$ & 0.003 \\
\hline \multirow{2}{*}{ Swine } & S. aureus & $\begin{array}{l}\text { Lemongrass } \\
\text { Clove }\end{array}$ & $\begin{array}{l}\mathrm{y}=-1.583^{* *+0}+090^{* *} \mathrm{xr}^{2}=0.962 \\
\mathrm{y}=-1.323^{*}+0.043^{*} \mathrm{xr}^{2}=0.833\end{array}$ & $<0.001$ \\
\hline & Salmonela sp. & $\begin{array}{l}\text { Lemongrass } \\
\text { Clove }\end{array}$ & $\begin{array}{l}y=-0.573^{*}+0.018^{* *} \mathrm{xr}^{2}=0.807 \\
\mathrm{y}=-0.979^{*}+0.050^{* *} \mathrm{xr}^{2}=0.983\end{array}$ & 0.003 \\
\hline Bovine & Salmonela $\mathrm{sp}$. & $\begin{array}{l}\text { Lemongrass } \\
\text { Clove }\end{array}$ & $\begin{array}{l}\mathrm{y}=-1.438^{*}+0.099 * * \mathrm{xr}^{2}=0.923 \\
\mathrm{y}=-2.313 * * 0.087 * \mathrm{xr}^{2}=0.929\end{array}$ & $<0.001$ \\
\hline
\end{tabular}

TIM: Estimation of p-Value for the model identity test in order to verify if the adjusted equations (curves) for lemongrass and clove are statistically the same or different. Coefficients accompanied by ${ }^{n s}$ are not significant at the $5 \%$ level of significance by the $t$ test. Coefficients accompanied by $*$ and $* *$ are significant at the 5 and $1 \%$ probability level, respectively. 
When analyzing the strains of $S$. aureus from different origins, compared to the essential oils studied, it was verified that there was a distinct behavior towards each oil. It was observed that there was no statistical difference in the diameter of the inhibition halo from the action of the lemongrass oil on the strains isolated from different animal species
(Figure 1A). However, it was observed that for strains isolated from bird feces, the clove essential oil provided greater halo inhibition and statistical difference in the concentration of $160 \mu \mathrm{ml}^{-1}$ (p $<0.05$ ) relative to the halo of inhibition of the same oil against the same microorganism isolated from swine feces (Figure 1B).

Figure 1. Antimicrobial activity of essential oils of lemongrass (A) and clove (B) against S. aureus strains from poultry feces and from swine feces and dose-response of different concentrations of essential oils of lemongrass and clove against strains of S. aureus from poultry feces (C) and from swine feces (D).
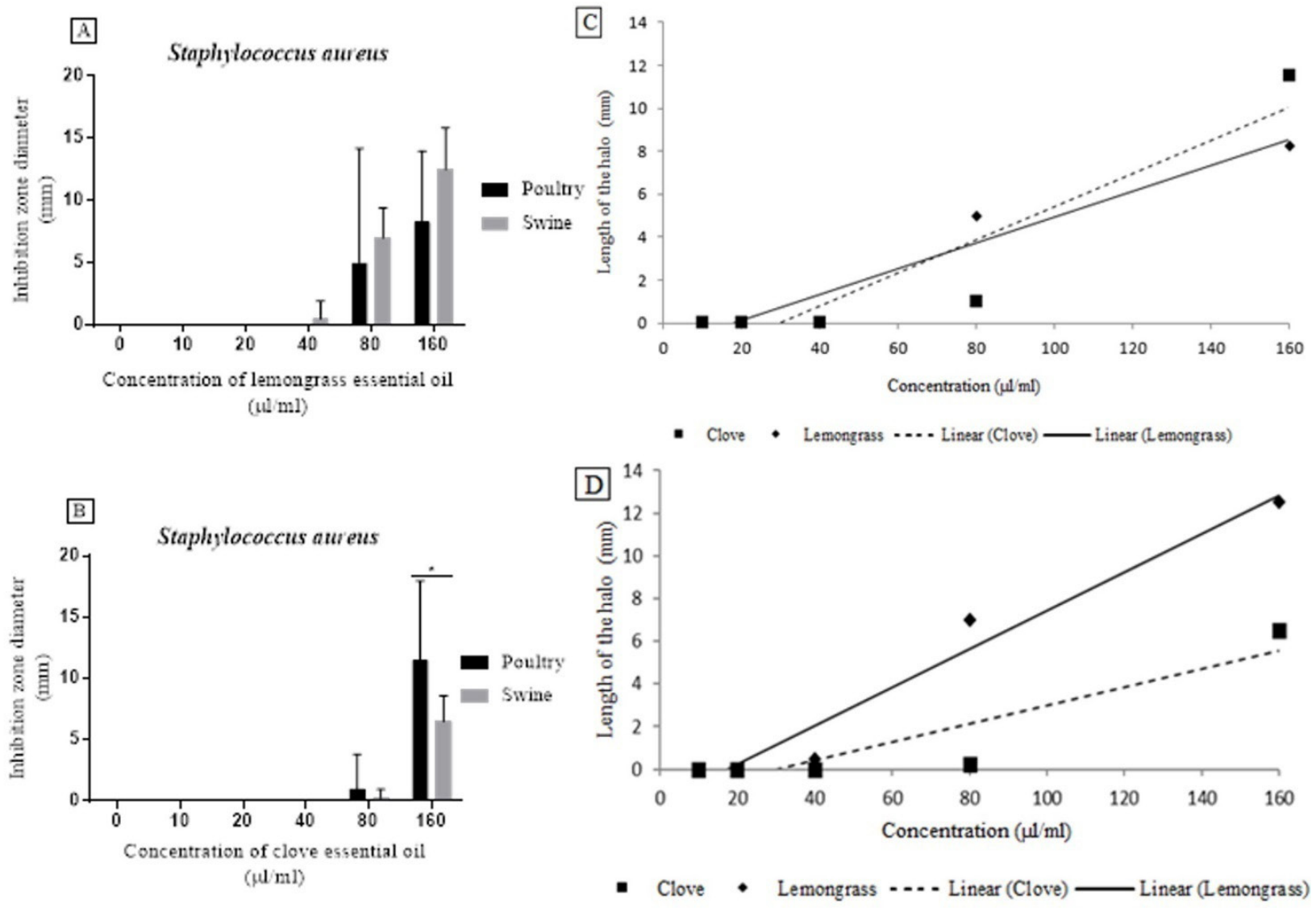

These results have shown that strains of $S$. aureus from poultry are more sensitive to essential oils, at least as far as clove essential oil is concerned.

On the contrary, when comparing the inhibition halo promoted by the essential oils and the inhibition halo formed in the control group (without the presence of essential oil), it was observed that both oils were efficient in inhibiting bacterial growth, although they were used in high concentrations. In view of this, these essential oils can be seen as promising alternatives to the use of conventional antibiotics. Silveira et al. (2012), using solid-media diffusion method, found that essential lemongrass oils strongly inhibited all gram-positive bacteria tested, and this oil showed greater inhibition in $S$. 
aureus than did ampicillin. Craveiro et al. (1981), found excellent results for $S$. aureus using clove essential oil. It attributed its excellent bactericidal properties to eugenol, a major component constituting $80-90 \%$ of the essential oil of this plant. According to the authors, eugenol causes inhibition in the production of amylase and proteases by the cell, as well as its deterioration and lysis, based on the observation that this active principle is widely used in dentistry as a component of sealants and other antiseptic products.

Figure 1 (C-D) shows that the essential oils of lemongrass and clove have inhibitory bacterial action in a dose dependent manner, both for strains of $S$. aureus of poultry and of swine. Greater inhibition halo diameter was noted with increasing concentrations used. What could explain this result is the method used for the determination of an antibiogram, which is not specific for the inhibitory effect of essential oils, and this may influence the diffusibility of the same (COX et al., 2000). It is important to note that the formation of the inhibition halo from the $80 \mu \mathrm{l} \mathrm{ml}{ }^{-1}$ concentration may reflect this (Figure 1).

When evaluating Salmonella sp. of different origins it was observed that for this isolated microorganism of swine feces obtained better inhibition of growth when using clove oil (Figure 2), a similar result was found when evaluating the dose response where in we observed greater halo diameter as the concentration of the oils increases.

When evaluating the results of the oils studied in this isolated strain of bovine feces, it was observed that the lemongrass oil obtained significant results in the concentrations of 160 and $80 \mu \mathrm{ml}^{-1}$ and obtained a better dose response in relation to the halo diameter and the concentrations (Figure 2). In both cases, the essential oil of lemongrass presented a larger diameter of the inhibition halo in relation to strains isolated from bovine and swine feces $(\mathrm{p}<$ 0.05) (Figure 2).
When evaluating the dose response of the strains of Salmonella of different origins to the oils, it was noticed that there was difference in the action of the oils on the strains studied. The lemongrass oil presented a greater halo of inhibition in relation to the concentrations; at the concentration of $160 \mu \mathrm{lml}$ ${ }^{-1}$, both oils presented similar results and efficiency. When the same strain from swine was evaluated, it was verified that clove oil obtained a better dose response. The difference in the results of the action of the oils tested against the same microorganism, but from different sources, may be related to selective pressure, mutation, or resistance genes (HOLMES et al., 2016). Clove oil is composed mostly of eugenol, which is responsible for the antimicrobial activity of the oil, since it has the capacity to penetrate the cytoplasmic membrane of the microorganism thereby increasing the non-specific permeability of the same, which can cause the rupture of membrane and microbial death (AFFONSO et al., 2012).

In other studies, the authors describe the activity of clove presenting different sizes of growth inhibiting halos of $S$. aureus (ALMEIDA et al., 2013), E. coli (AJIBOYE et al., 2016) and Salmonella (SOLARTE et al., 2017), isolated from clinical or food species. Studies that report the activity of this oil on the inhibition of bovine, swine and bird feces isolates were not found in the literature.

Lemongrass essential oil has citral as its main component. This oil inhibits the growth of pathogenic microorganisms in plants, animals, and humans and, in addition, inhibits the activity of the enzyme $\beta$-glucuronidase (DESAI; PARIKH, 2012).

Studies carried out using lemongrass essential oil against microorganisms such as $S$. aureus (SANTOS et al., 2017) E. coli (AZEVEDO et al., 2016; ASSIS et al., 2017) and Salmonella enterica subsp. enterica (ATCC 6017) (ASSIS et al., 2017) isolated from different sources presented different inhibition halos. 
Figure 2. Antimicrobial activity of essential oils of lemongrass (A) and clove (B), against Salmonella strains from poultry feces and from swine feces and dose-response of different concentrations of the essential oils of lemongrass and cloves of Salmonella from bovine feces (C) and swine feces (D).
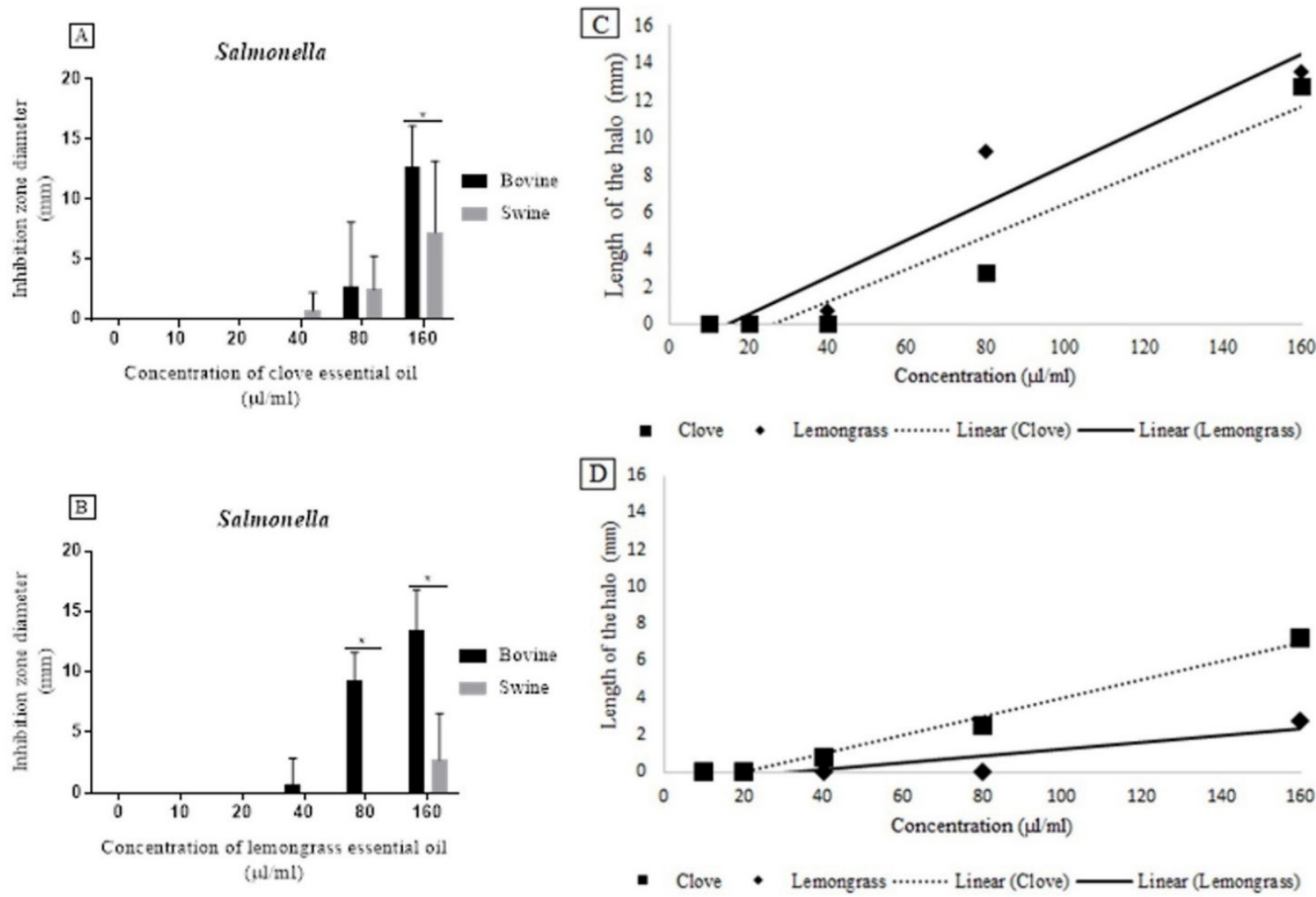

For the E. coli strain only the response dose was evaluated (Figure 3), since it was only withdrawn from a single origin, making a comparison impossible. When observing the dose response of the essential oils' actions against Escherichia coli strains isolated from poultry, a greater diameter of the halo of clove oil inhibition zone was observed in relation to the increase in concentration, differing statistically from that of the halo generated by the lemongrass essential oil $(p<0.05)$. In a study carried out by Patterson et al. (2017), evaluating the efficiency of the essential oils of cinnamon, clove, lavender, lemongrass, eucalyptus, oregano, rosemary, and thyme, against gram positive and gram negative strains, it was found that, as in the present study, clove oil from India presented larger halos of inhibition against E.coli than did lemongrass oil. In this same study it was found that the lemongrass essential oil inhibition halos were larger against gram-positive organisms and were larger than the vancomycin positive control used in the work.

According to Guo et al. (2017), there is a difference between the layers of gram-positive bacteria compared to gram-negative bacteria, which may lead to different actions of the essential oils on the microorganisms. In addition, the antimicrobial action of the oil becomes more efficient with respect to the oil to be used, not to the microorganism. According to Blair et al. (2014), bacteria may present resistance owing to the functional or structural characteristics belonging to each species. 
Figure 3. Dose response of strains of Escherichia coli from poultry feces, compared to different concentrations of essential oils of lemongrass and clove.

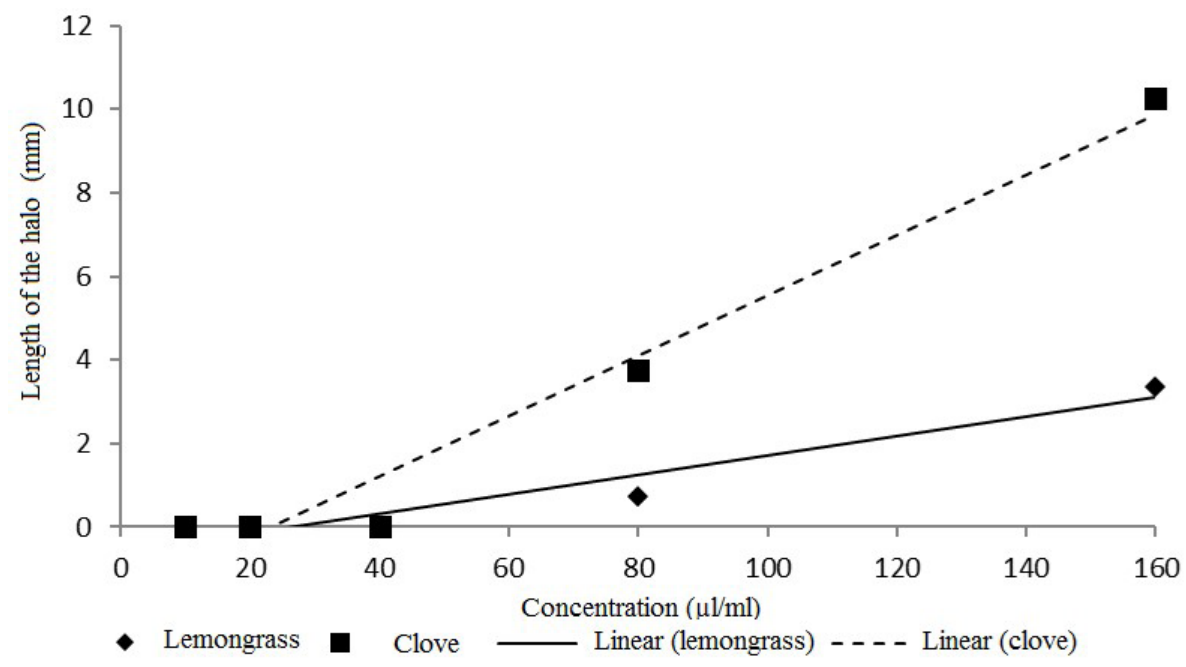

Both oils present potential for use as performance enhancers in animal feeds and for disease treatment, but different in vivo activity tests are required to assess the palatability of oils in animal feed and animal products, as well as the stability of the oils in the presence of the organic matter present in the rations.

Previous studies using these oils in animal feed have differing results. Almeida et al. (2018) used lemongrass essential oil (Cymbopogon flexuosus) and pedestrian tea (Lippia aff. Rotundifolia) verified that there were no significant alterations in the intestinal microbiota of broilers compared to positive control groups (supplemented with $10 \mathrm{ppm}$ enramycin and $42 \mathrm{ppm}$ salinomycin) and negative control (formulated ration), and Nogueira et al. (2017) evaluated effect of lemongrass essential oil on the performance and yield of organs and commercial cuts of broiler chickens and concluded that the use of lemon grass essential oil in the chicken broiler diet negatively affects their productive characteristic, due to lower gizzard and drumstick weights. When testing oil stability in feeds for broiler chickens Assis et al. (2017) observed that micro-encapsulated lemon grass essential oil improved stability for up to seven days storage.
In researches using cloves in animal feed, positive results were observed, Hussein et al. (2018) used cold-pressed clove essential oil in Japanese quail supplementation found that the use of $1.5 \mathrm{~mL} / \mathrm{kg}$ of the oil in the diet can improve growth performance, reduce intestinal and pathogenic bacteria in the gut and improve the state of health. Mukhtar (2011) evaluated the effect of addition different levels of clove oil, as a natural growth promoter in broiler chickens. The results verified that clove oil can be used up to $600 \mathrm{mg} / \mathrm{kg}$ as an alternative natural growth promoter substance instead of antibiotic. Morsy et al. (2012) observed that the use of essential oils may alter ruminal fermentation and reduce the proportion of acetate thereby improving milk protein in lactating goats.

Therefore, further studies are needed to evaluate these oils in animal feed to verify their effects on the body and to find the dose suitable for each species. Another factor to be taken into account is the type of oil that will be used, because this factor influences the performance and growth of the animals (CHOWDHURY et al., 2018).

In view of the results obtained, it is suggested that the essential oils can be used alone or in 
combination with antimicrobial agents to control multi-resistant bacteria, although further in vivo studies on the safety and the effect of the essential oils are required. The complex composition and different mechanisms of action of the essential oils may be an advantage over other antimicrobials to prevent the development of resistance in pathogenic bacteria (KNEZEVIC et al., 2016; YAP et al., 2014).

The essential oils studied here presented promising results as possible antimicrobials against pathogens isolated from feces of production animals, indicating the possibility for use in place of performance enhancers added to feed. However, more studies are needed to elucidate the maximum efficiency of these oils when included in the diet and their bio accessibility in the digestive tract of the animals.

\section{Conclusion}

The essential oils of lemongrass (Cymbopogon flexuosus Steud. Wats) and clove (Syzygium aromaticum) have antimicrobial action in vitro against Salmonella sp., Escherichia coli and Staphylococcus aureus isolated from feces from production animals and this antimicrobial activity is dose dependent.

\section{Funding}

This work was supported by FAPEMIG, CAPES, CNPq, UFMG/PRPq,

\section{Acknowledgements}

Laboratório de Química Instrumental - Instituto de Ciências Agrárias UFMG.

\section{References}

AFFONSO, R. S.; RENNÓ, M. N.; SLANA, G. B. C. A.; FRANÇA, T. C. C. Chemical and biological aspects of the essential oil of indian cloves. Revista Virtual de
Química, Rio de Janeiro, v. 4, n. 2, p. 146-161, 2012. DOI: 10.5935/1984-6835.20120012.

AGÊNCIANACIONAL DE VIGILÂNCIA SANITÁRIA - ANVISA. Ministério de Saúde e a Organização PanAmericana da Saúde. Organização Mundial da Saúde Representação do Brasil. Controle interno de qualidade para testes de sensibilidade a antimicrobianos. Termo de Cooperação $\mathrm{n}^{\circ} 37$ (TC 37). Brasília: OPAS/ANVISA/ SVS, mar. 2006. Disponível em: goo.gl/6eTzLf. Acesso em: 10 fev. 2018.

AJIBOYE, T. O.; MOHAMMED, A. O.; BELLO, S. A.; YUSUF, I. I.; IBITOYE, O. B.; MURITALA, H. F.; ONAJOBI, I. B. Antibacterial activity of Syzygium aromaticum seed: Studies on oxidative stress biomarkers and membrane permeability. Microbial Pathogenesis, v. 95, p. 208-215, jun. 2016. DOI: 10.1016/j. micpath.2016.03.011.

ALMEIDA, A. C.; OLIVEIRA, L.; PAULO, P. D.; MARTINS, E. R.; SOUZA, R. M.; FIGUEIREDO, L. D. S.; SANTOS, C. A.; FONSECA, H. C. Potencial antimicrobiano dos óleos essenciais de cravo-daíndia (Syzygium aromaticum L.) e alfavacão (Ocimum gratissimum L.) em carne moída de ovinos contaminada experimentalmente com Staphylococcus aureus. Revista Brasileira de Ciência Veterinária, Niterói, v. 20, n. 4, p. 248-251, out./dez. 2013. DOI: 10.4322/rbcv.2014.010.

ALMEIDA, E. H.; MARTINS, E. R.; ALMEIDA, A. C.; NOGUEIRA, W. C. L.; AZEVEDO, I. L.; ASSIS, Y. P. A. Influência dos óleos essenciais de capim-limão e chá-de-pedestre na saúde intestinal de frangos de corte. Revista Cientifica de Avicultura e Suinocultura, Manaus, v. 3, n. 2, p. 43-54, jul. 2018. Disponível em: http:// www.periodicos.ufam.edu.br/RECAS/article/view/4484. Acesso em: 17 abr. 2019.

ASSIS, Y. P. A. S.; ALMEIDA, A. C.; NOGUEIRA, W. C. L.; SOUZA, C. N.; GONÇALVES, S. F.; SILVA, F. E. G.; SANTOS, V. K. F. R.; MARTINS, E. R. Antibacterial activity and stability of microencapsulated lemongrass essential oil in feeds for broiler chickens. Revista Brasileira de Saúde e Produção Animal, Salvador, v. 18 , n. 4, p. 587-593, dez. 2017. DOI: 10.1590/ s151999402017000400009.

AZEVEDO, I. L.; ALMEIDA, A. C.; MARTINS, E. R.; NOGUEIRA, W. C. L.; FARIA FILHO, D. E.; OLIVEIRA, S. P.; PRATES, J. P. B.; SOUZA, C. N. Eficácia in vitro do óleo essencial de capim-limão (Cymbopogon flexuosussteud. wats.) frente a bactérias entéricas de origem avícola. Acta Veterinaria Brasilica, Mossoró, v. 10, n. 1, p. 25-31, mar. 2016. DOI: 10.21708/ avb.2016.10.1.5467. 
BLAIR, J. M.; WEBBER, M. A.; BAYLAY, A. J.; OGBOLU, D. O.; PIDDOCK, L. J. Molecular mechanisms of antibiotic resistance. Nature Reviews Microbiology, v. 13, n. 1, p. 42-51, dez. 2014. DOI: 10.1038/nrmicro3380.

BURT, S. Essential oils: their antibacterial properties and potential applications in foods a review. International Journal of Food Microbiology, Torino, v. 94, n. 3, p. 223253, ago. 2004. DOI: 10.1016/j.ijfoodmicro.2004.03.022.

CHOWDHURY, S.; MANDAL, G. P.; PATRA, A. K. Different essential oils in diets of chickens: 1. Growth performance, nutrient utilisation, nitrogen excretion, carcass traits and chemical composition of meat. Animal Feed Science And Technology, v. 236, p. 86-97, fev. 2018. DOI: 10.1016/j.anifeedsci.2017.12.002.

CLINICAL AND LABORATORY STANDER INSTITUTE - CLSI. M02-A12 Performance standards for antimicrobial disk susceptibility tests. Clinical and Laboratory Stander Institute, Wayne, v. 35, n. 1, p. 1-236, jan. 2015. Available at: goo.gl/stUv3r. Accessed at: 15 fev. 2018.

COMISSÃO EUROPEIA. Regulamento de Execução (UE) n. ${ }^{\circ} 872 / 2012$ da Comissão, de 1 de outubro de 2012. Adota a lista das substâncias aromatizantes prevista no Regulamento (CE) n. ${ }^{\circ} 2232 / 96$ do Parlamento Europeu e do Conselho, inclui essa lista no anexo I do Regulamento (CE) n. ${ }^{\circ} 1334 / 2008$ do Parlamento Europeu e do Conselho e revoga o Regulamento (CE) n. ${ }^{\circ}$ 1565/2000 e a Decisão 1999/217/CE (texto relevante para efeitos do EEE). Jornal Oficial [da] União Europeia, Bruxelas, 2 out. 2012. Disponível em: goo.gl/HK6gCV. Acesso em: 1 mar. 2018.

COSTA, L. B.; TSE, M. L. P.; MIYADA, V. S. Extratos vegetais como alternativas aos antimicrobianos promotores de crescimento para leitões recémdesmamados. Revista Brasileira de Zootecnia, Viçosa, MG, v. 36, n. 3, p. 589-595, jun. 2007. DOI: 10.1590/ s1516-35982007000300011.

COX, S. D.; MANN, C. M.; MARKHAM, J. L.; BELL, H. C.; GUSTAFSON, J. E.; WARMINGTON, J. R.; WYLLIE, S. G. The mode of antimicrobial action of the essential oil of Melaleuca alternifolia (tea tree oil). Journal of Applied Microbiology, v. 88, n. 1, p. 170-175, dez. 2000. DOI: 10.1046/j.1365-2672.2000.00943.x.

CRAVEIRO, A. A.; FERNANDES, A. G.; ANDRADE, C. H. S.; MATOS, F. J. A.; ALENCAR, J. W.; MACHADO, M. I. L. Óleos essenciais de plantas do Nordeste. Fortaleza: UFC- Departamento de Química Orgânica e Inorgânica, 1981. 210 p.

DESAI, M. A.; PARIKH, J. Hydrotropic extraction of citral from Cymbopogon flexuosus (Steud.) wats. Industrial Engineering Chemistry Research, v. 51, n. 9, p. 3750-3757, fev. 2012. DOI: 10.1021/ie202025b.

DEVI, K. P.; NISHA, S. A.; SAKTHIVEL, R.; PANDIAN, S. K. Eugenol (an essential oil of clove) acts as an antibacterial agent against Salmonella typhi by disrupting the cellular membrane. Journal of Ethnopharmacology, v. 130, n. 1, p. 107-115, jul. 2010. DOI: $10.1016 /$ j.jep.2010.04.025.

DI PASQUA, R.; HOSKINS, N.; BETTS, G.; MAURIELLO, G. Changes in membrane fatty acids composition of microbial cells induced by addiction of thymol, carvacrol, limonene, cinnamaldehyde, and eugenol in the growing media. Journal of Agricultural and Food Chemistry, Washington v. 54, n. 7, p. $2745-$ 2749, abr. 2006. DOI: 10.1021/jf0527221

FALEIRO, M. L.; MIGUEL, M. G. Use of essential oils and their components against multidrug-resistant bacteria. In: RAJ, M.; KON, K. Fighting multidrug resistance with herbal extracts, essential oils and their components. Oxford: Academic Press, 2013. p. 65-94.

FISHER, K.; PHILLIPS, C. A. The effect of lemon, orange and bergamot essential oils and their components on the survival of Campylobacter jejuni, Escherichia coli O157, Listeria monocytogenes, Bacillus cereus and Staphylococcus aureus in vitro and in food systems. Journal of Applied Microbiology, v. 101, n. 6, p. 1232-1240, dez. 2006. DOI: 10.1111/j.13652672.2006.03035.x.

GONZALES, E.; MELLO, H. H. C.; CAFÉ, M. B. Uso de antibióticos promotores de crescimento na alimentação e produção animal. Revista UFG: Dossiê Pecuária, Goiânia, v. 13, n. 13, p. 48-53, dez. 2012. Disponível em: goo.gl/S4Rrnz. Acesso em: 2 fev. 2018.

GUO, N.; ZANG, Y. P.; CUI, Q.; GAI, Q. Y.; JIAO, J.; WANG, W.; GANG ZU, Y.; FU, Y. J. The preservative potential of Amomumtsaoko essential oil against E. coil, its antibacterial property and mode of action. Food Control, v. 75, p. 236-245, maio 2017. DOI: 10.1016/j. foodcont.2016.12.013.

HOLMES, A. H.; MOORE, L. S.; SUNDSFJORD, A.; STEINBAKK, M.; REGMI, S.; KARKEY, A.; GUERION, P. J.; PIDDOCK, L. J. Understanding the mechanisms and drivers of antimicrobial resistance. The Lancet, London, v. 387, n. 10014, p. 176-187, jan. 2016. DOI: $10.1016 / \mathrm{s} 0140-6736(15) 00473-0$.

HUDSON, J. A.; FREWER, L. J.; JONES, G.; BRERETON, P. A.; WHITTINGHAM, M. J.; STEWART, G. The agri-food chain and antimicrobial resistance: a review. Trends in Food Science Technology, 
Cambridge, v. 69, p. 131-147, nov. 2017. DOI: 10.1016/j. tifs.2017.09.007.

HUSSEIN, M. M.; ABD EL-HACK, M. E.; MAHGOUB, S. A.; SAADELDIN, I. M.; SWELUM, A. A. Effects of clove (Syzygium aromaticum) oil on quail growth, carcass traits, blood components, meat quality, and intestinal microbiota. Poultry Science, Savoy, v. 98, n. 1, p. 319329, ago. 2018. DOI: 10.3382/ps/pey348.

HYLDGAARD, M.; MYGIND, T.; MEYER, R. L. Essential oils in food preservation: mode of action, synergies, and interactions with Food Matrix Components. Frontiers in Microbiology, v. 3, p. 1-12, jan. 2012. DOI: 10.3389/fmicb.2012.00012.

KNEZEVIC, P.; ALEKSIC, V.; SIMIN, N.; SVIRCEV, E.; PETROVIC, A.; MIMICA-DUKIC, N. Antimicrobial activity of Eucalyptus camaldulensis essential oils and their interactions with conventional antimicrobial agents against multi-drug resistant Acinetobacter baumannii. Journal of Ethnopharmacology, Ireland, v. 178, p. 125136, fev. 2016. DOI: 10.1016/j.jep.2015.12.008.

KRUMPERMAN, P. H. Multiple antibiotic resistance indexing of Escherichia coli to identify high-risk sources of fecal contamination of foods. Applied and Environmental Microbiology, Washington, v. 46, n. 1, p. 165-170, jul. 1983. Available at: goo.gl/i8sVXd. Accessed at: 20 fev. 2018.

MAGIORAKOS, A. P.; SRINIVASAN, A.; CAREY, R. B.; CARMELI, Y.; FALAGAS, M. E.; GISKE, C. G.; HARBARTH, S.; HINDLER, J. F.; KAHLMETER, G.; OLSSON-LILJEQUIST, B.; PATERSON, D. L.; RICE, L. B.; STELLING, J.; STRUELENS, M. J.; VATOPOULOS, A.; WEBER, J. T.; MONNET, D. L. Multidrug-resistant, extensively drug-resistant and pandrug-resistant bacteria: an international expert proposal for interim standard definitions for acquired resistance. Clinical Microbiology and Infection, v. 18, n. 3, p. 268-281, mar. 2012. DOI: 10.1111/j.1469-0691.2011.03570.x.

MORSY, T. A.; KHOLIF, S. M.; MATLOUP, O. H.; ABDO, M. M.; EL-SHAFIE, M. H. Impacto dos óleos de anis, cravo e zimbro como aditivos na alimentação no desempenho produtivo das cabras em lactação. International Journal of Dairy Science, v. 7, n. 1, p. 2028, 2012. DOI: 10.3923/ijds.2012.20.28

MUKHTAR, M. A. The effect of dietary clove oil on broiler performance. Australian Journal of Basic and Applied Sciences, Faisalabad, v. 5, n. 7, p. 49-51, 2011. Available at: http://www.insipub.com/.../49-51.pdf

NOGUEIRA, W. C. L.; RIPPEL, D. N.; ALMEIDA, A. C.; SANTOS, E. V.; WENCESLAU, R. R.; FERREIRA, F. Lemon grass essential oil on productive characteristics of broiler chickens. Acta Veterinaria Brasilica, Mossoró, v. 11, n. 2, p. 93-97, jun. 2017. DOI: 10.21708/ avb.2017.11.2.6511

PATTERSON, J. E.; MCELMEEL, M. L.; WIEDERHOLD, N. P. In vitro susceptibility testing of essential oils against gram-positive and gram-negative clinical isolates, including Carbapenem-Resistant Enterobacteriaceae (CRE). Open Forum Infectious Diseases, v. 4, n. 1, p. 370-370, out. 2017. DOI: 10.1093/ ofid/ofx163.907.

PICKLER, L.; SANTIN, E.; SILVA, A. V. F. Alternativas aos antibióticos para equilibrar a microbiota gastrointestinal de frangos. Archives of Veterinary Science, Curitiba, v. 16, n. 3, p. 1-13, dez. 2011. DOI: 10.5380/avs.v16i3.18300.

QUINN, P. J.; MARKEY, B. K.; CARTER, M. E.; DONNELLY, W. J.; LEONARD, F. C. Agentes microbianos e produção de doença: causas bacterianas de mastite bovina. In: QUINN, P. J.; MARKEY, B. K.; CARTER, M. E.; DONNELLY, W. J.; LEONARD, F. C. (Ed.). Microbiologia veterinária e doenças infecciosas. Porto Alegre: Artmed, 2005. p. 451-460.

SANTOS, P. H. A. S.; CUNHA, G. S. P.; OLIVEIRA, S. P.; SILVA, L. M. V.; SOUZA, C. N.; NOGUEIRA, M. O.; SILVA, J. M. A.; PORTO, R. R.; ALMEIDA, A. C. Sensibilidade de Staphylococcus sp. oxacilina resistentes ao óleo essencial de capim-limão (Cymbopogonflexuosus (steud) watts). Revista Eletrônica Acervo Saúdel Electronic Journal Collection Health, Campinas, v. 8, n. 8, p. 573-577, 2017. Disponível em: https://www. acervosaude.com.br/doc/REAS43.pdf. Acesso em: 20 fev. 2018.

SILVA, K. C.; LINCOPAN, N. Epidemiologia das betalactamases de espectro estendido no Brasil: impacto clínico e implicações para o agronegócio. Jornal Brasileiro de Patologia e Medicina Laboratorial, Rio de Janeiro, v. 48, n. 2, p. 91-99, abr. 2012. DOI: 10.1590/ s1676-24442012000200004

SILVEIRA, S. M. D.; CUNHA JÚNIOR, A.; SCHEUERMANN, G. N.; SECCHI, F. L.; VIEIRA, C. R. W. Chemical composition and antimicrobial activity of essential oils from selected herbs cultivated in the South of Brazil against food spoilage and foodborne pathogens. Ciência Rural, Santa Maria, v. 42, n. 7, p. 1300-1306, jul. 2012. DOI: $10.1590 / \mathrm{s} 0103-84782012000700026$.

SOLARTE, A. L.; ASTORGA, R. J.; AGUIAR, F.; GALÁN-RELAÑO, Á.; MALDONADO, A.; HUERTA, B. Combination of antimicrobials and essential oils as an alternative for the control of Salmonella enteric multiresistant strains related to foodborne disease. Foodborne Pathogens and Disease, v. 14, n. 10, p. 558563, out. 2017. DOI: 10.1089/fpd.2017.2295 
SOMOLINOS, M.; GARCÍA, D.; CONDÓN, S.; MACKEY, B.; PAGÁN, R. Inactivation of Escherichia coli by citral. Journal of Applied Microbiology, v. 108, n. 6, p. 1928-1939, out. 2009. DOI: 10.1111/j.13652672.2009.04597.x.

VARGHESE, M.; ROYMON, M. G. Studies on antibiotic resistance profiles of thermotolerant Escherichia coli and multiple antibiotic resistance index of different water sources. Recent Research in Science and Technology, v. 5, n. 2, p. 68-72, 2013. Available at: goo.gl/9HD88w. Accessed at: 24 fev. 2018.
XIE, Y.; YANG, Z.; CAO, D.; RONG, F.; DING, H.; ZHANG, D. Antitermitic and antifungal activities of eugenol and its congeners from the flower buds of Syzgium aromaticum (clove). Industrial Crops and Products, v. 77, p. 780-786, dez. 2015. DOI: 10.1016/j. indcrop.2015.09.044.

YAP, P. S. X.; YIAP, B. C.; PING, H. C.; LIM, S. H. E. Essential oils, a new horizon in combating bacterial antibiotic resistance. The Open Microbiology Journal, v. 8, n. 1, p. 6-14, fev. 2014. DOI: $10.2174 / 1874285801408010006$. 